\title{
ESTÉTICA E DIALOGISMO: O PAPEL DA LITERATURA NA FORMAÇÃO DA CIDADANIA
}

AESTHETICS AND DIALOGISM: THE ROLE OF LITERATURE IN THE DEVELOPMENT OF CITIZENSHIP

Ana Cristina Ferreira-Pinto Bailey

Doutora em Literatura Brasileira e Hispano-Americana pela Tulane University.

Department Romance Languages Washington and Lee University (WLU)

Lexington - VA - USA

Endereço:

Dept. Romance Languages 204 West Washington Street Lexington, VA 24450-2116

E-mail:

pinto-baileyac@wlu.edu

RESUMO

Este ensaio examina o caráter dialógico da obra literária e a sua função na formação do sujeito leitorinclusive em sua cidadania-, assim como instrumento catalisador de transformações sociais e políticas. O ensaio toma como objetos de análise a obra da escritora chicana Gloria Anzaldúa e a da brasileira Eliane Potiguara, duas autoras que unem ativismo político e criação estética em sua literatura.

PALAVRAS-CHAVE: Dialogismo. Eliane Potiguara. Gloria Anzaldúa.

ABSTRACT

This essay examines the dialogical character of literature, and its role in the reader's development and citizenship, as well as its role as a catalyst of social and political change. The objects of analysis of this essay are the Mexican-American writer, and the Brazilian writer Eliane Potiguara; two authors who bring together aesthetics and political activism in their literature.

KEY WORDS: Dialogism. Eliane Potiguara. Gloria Anzaldúa.

INTRODUÇÃO

Em um ensaio sobre "cultura versus arte" no contexto brasileiro da distensão política de finais dos anos setenta, Silviano Santiago declara que a impossibilidade de um debate político-cultural no espaço da sociedade brasileira naquele momento levou esse debate para o campo da arte, "considerando-se esta não mais como manifestação exclusiva das belles lettres"—ou seja, da produção de "letrados" identificados ainda com um ideário político-cultural europeizante, como Ángel Rama discute em La ciudad letrada (1984) —, mas sim, continua Santiago, "como fenômeno multicultural que estava servindo para criar novas e plurais identidades sociais" (2004a, p. 137). Esse fenômeno multicultural começa a fazer-se mais explícito no Brasil à medida que cresce o repúdio por 
parte de vários segmentos populacionais à ditadura militar, e coincide com manifestações plurivocais semelhantes em outras partes das Américas.

As vozes de mulheres, homossexuais, negros, indígenas e outras minorias étnicas vêm enriquecer e, ao mesmo tempo, problematizar um debate social, político e cultural sobre conceitos tais como nação, identidade nacional, produção cultural e igualdade social. A emergência dessa multiplicidade de vozes começa a borrar distinções entre categorias que anteriormente tinham-se mantido mais ou menos inabaladas, embora no Brasil viessem sendo pouco a pouco minadas desde as primeiras décadas do século vinte. E uma dessas categorias diz respeito exatamente ao próprio espaço onde tem lugar esse debate. O campo da arte, ou seja, o campo da expressão estética que, portanto, inclui a literatura, torna-se arena de debate e inquirição, tanto subjetiva como coletiva, ou em outras palavras, tanto individual (introspecção do EU) como do grupo social (exame da realidade exterior). E mais, lembrando que o "pessoal é político," como afirma o slogan do movimento feminista nos Estados Unidos de finais dos anos sessenta, a autointrospecção do sujeito e a abordagem de questões consideradas pessoais transcendem os limites do espaço privado para impactar o espaço público.

Levado pela arte, o debate político e social abandona os espaços predeterminados e hierarquizados do poder para multiplicar sua presença em vários lugares e por meio de vozes diversas: no museu de arte ou no bar; no ônibus ou no metrô; na sala de aula ou no shopping. Ao mesmo tempo, a arte insiste cada vez mais na participação de quem a consome, pois o agente do fazer estético e a sua mensagem vão complementar-se no outro, naquele que "lê" a obra de arte, seja esta visual, literária, musical, etc. Alfredo Bosi, discutindo especificamente o caso da poesia, considera que a "fala poética" permite o que ele chama de "encontro dos tempos": o lócus privilegiado em que o poema - ou o objeto estético - transcende seu contexto histórico para estabelecer um diálogo com outros tempos históricos, especificamente o tempo do leitor no ato da leitura, para completar-se nesse diálogo.

Vejam-se aqui dois exemplos breves; um, o poema "Fato", de Esmeralda Ribeiro, cuja composição gráfica concede àquele que o lê a eleição de como o ler e, assim, também a completude do seu significado:

Aboliram

não

\section{Escravidão}

A

condição

E o segundo exemplo, a instalação da artista venezuelana residente em Nova Iorque, Esperanza Mayobre, uma de muitas de suas obras sobre a urbe contemporânea. A obra em técnica mista, intitulada "La amable Candelaria vive su peor momento," pode ser vista como uma representação do ataque ao World Trade Center em setembro de 2001 e pressupõe a participação, mesmo que inadvertida, do visitante na ordenação das peças plásticas que a compõem:

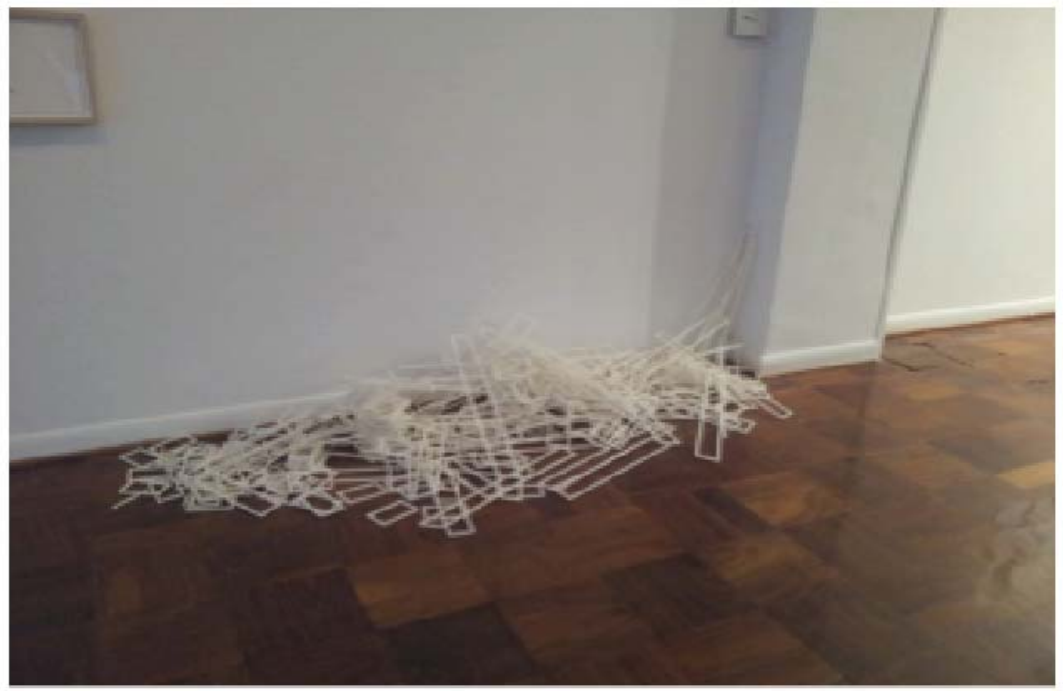

Nestes dois exemplos fica patente o caráter dialógico da obra de arte, segundo o conceito de "dialogismo" proposto por Mikhail Bakhtin. Julia Kristeva, que foi em grande parte responsável pela 
disseminação da obra de Bakhtin no hemisfério ocidental, entende dialogismo como "an open-ended play between the text of the subject and the text of the addressee" (KRISTEVA, 1986, p. 34), ou seja, um jogo ou diálogo aberto entre o "texto" do sujeito da enunciação e o "texto" do receptor, entendendo aqui "texto" como a posição ou a perspectiva única a partir da qual o receptor aborda o objeto estético, seja essa abordagem feita por meio da leitura, da escuta, do tato ou visão. Entretanto um ponto importante a levar-se em conta é que a obra de arte dialógica, ao pressupor que o receptor possui seu próprio "texto" (seu tempo histórico, nos termos de Bosi), pressupõe também que esse deixa de ser um simples receptor passivo para tornar-se um agente atuante no diálogo que se estabelece e na resultante produção do significado.

Kristeva ressalta que Bakhtin vê a palavra literária - e por extensão assim consideremos toda produção artística - não como um significado fixo, mas sim como um diálogo que resulta da interseção de vários planos textuais: do escritor, do leitor, do contexto cultural e histórico em que se processa o ato da leitura, etc. (KRISTEVA, 1986, p. 36). Daí que o significado gerado a partir do encontro entre o sujeito do enunciado e o receptor é sempre uma categoria "movediça," mutável, enquanto que esse encontro ou diálogo apresenta possibilidades transformadoras para o receptor por "ser parte da experiência que alicerça a sua formação (bildung)," esclarece Silviano Santiago (2004b, p. 169). Tais possibilidades transformadoras residem na ruptura em que implica o dialogismo, isto é, no ato de transgressão de códigos linguísticos, lógicos e sociais (KRISTEVA, 1986, p. 41, 58), possibilitado pela obra de arte.

Tendo em conta estas considerações iniciais, proponho-me aqui a examinar o caráter dialógico da obra literária e sua função como instrumento gerador de transformações tanto em nível do indivíduo - receptor atuante do enunciado - como em nível do coletivo social. Especificamente, pretendo indagar da função da literatura como instrumento formador da cidadania e também de seu papel catalisador de transformações a partir de um diálogo polifônico que se estabelece na sala de aula entre o indivíduo leitor, o docente, os outros componentes do grupo discente e o texto. Para tanto, examinarei a obra de duas escritoras e ativistas contemporâneas, a chicana (i.e. mexicanoamericana) Gloria Anzaldúa e a brasileira Eliane Potiguara. Logo discutirei brevemente o papel transformador e formador da cidadania que a literatura cumpre, a partir da recepção da obra destas e de outras autoras numa aula de graduação sobre a escrita latino-americana de autoria feminina.

\section{GLORIA ANZALDÚA E ELIANE POTIGUARA: LITERATURA E ATIVISMO POLÍTICO}

Gloria Anzaldúa, nascida no Texas em 1942, de uma família de trabalhadores rurais migrantes, e morta precocemente em 2004, é uma das escritoras contemporâneas mais influentes dos Estados Unidos, tendo recebido vários prêmios literários importantes. Sua obra inclui livros para crianças, poesia, crítica social e ensaio autobiográfico, e continua influenciando várias áreas de estudo, entre elas a literatura, a crítica feminista e a crítica cultural, os estudos chicanos e fronteiriços ("border studies"), e os estudos "queer" e de gênero ("gender"). Sua literatura caracteriza-se pela hibridez da forma, pois borra os limites entre gêneros literários, misturando poesia e prosa, ensaio autobiográfico e de cunho sociológico, assim como transgride códigos linguísticos, ao empregar em seu textos o inglês, o "spanglish," o espanhol padrão e outras variantes deste idioma, como, por exemplo, o espanhol chicano. É também uma literatura eminentemente carnavalesca no sentido bakhtiniano, entendendo carnavalesco como aquele discurso que “... breaks through the laws of language censored by grammar and semantics and, at the same time, is a social and political protest. There is no equivalence, but rather, identity between challenging official linguistic codes and challenging official law" (KRISTEVA, 1986, p. 36).

O protesto que a obra de Anzaldúa manifesta, sendo social e político, origina-se, entretanto, na sua experiência pessoal; de fato, ela é uma das melhores representações do conceito de que “o pessoal é político." Em livros como Borderlands/La frontera: The New Mestiza (1987) e This Bridge Called My Back (1981), que ela organizou em colaboração com Cherríe Moraga, outra escritora chicana, Anzaldúa escreve e inscreve uma identidade própria, que ela mesma define e constrói por meio da palavra, em oposição a imagens identitárias que Ihe haviam sido impostas pela sociedade, definidas a partir de uma visão discriminatória de sua identidade, com as quais Anzaldúa conviveu desde a infância. 
Devido a uma condição endocrinológica com que nasceu, Anzaldúa ficou menstruada numa idade muito tenra, o que fez com que desde criança enfrentasse rejeição e discriminação associadas ao corpo feminino. Além disso, ela enfrentou mais tarde discriminação por sua orientação homossexual, assim como discriminação de classe e étnica, esta uma herança compartilhada pelos povos americanos de origem indígena desde os tempos da conquista ibérica. Seu livro Borderlands traça precisamente o trajeto que a autora empreende por meio da escrita, desde a autorrejeição e a alienação advindas da discriminação sofrida, à conscientização e à aceitação do Eu e, finalmente, a uma postura de desafio e resistência.

Entretanto, enquanto que a identidade pessoal da autora ocupa uma posição central em sua literatura, esta sempre se direciona para a realidade exterior e para a possibilidade de efetuarmos - escritora e leitores - transformações sociais. A este respeito, afirma a crítica que a autora "draws from her personal experiences to develop a sophisticated theory and praxis of transformation that posits self-reflection and self-change as the foundation for social justice work" (KEATING; GONZÁLEZLÓPEZ, 2011, p. 1). Esta é uma razão por que a perspectiva narrativa e poética em sua obra muda constantemente da primeira à terceira pessoa, para não raramente concluir dirigindo-se diretamente a quem a lê. Por exemplo, no sétimo capítulo de Borderlands, "La conciencia de la mestiza. Towards a New Consciousness," Anzaldúa fala da sua própria conscientização identitária frente à sociedade, e de uma nova consciência da mulher chicana, para logo incluir um "nós" coletivo:

From this racial, ideological, cultural and biological cross-polinization, an "alien" consciousness is presently in the making-a new mestiza consciousness, una conciencia de mujer. It is a consciousness of the Borderlands.

Una lucha de fronteras / A Struggle of Borders

Because I, a mestiza,

Continually walk out of one culture and into another,

because I am in all cultures at the same time,

. .

Estoy norteada por todas las voces que me hablan simultáneamente.

... At some point, on our way to a new consciousness, we will have to leave

the opposite bank, the split between the two combatants somehow healed. . . .

The possibilities are numerous once we decide to act and not react. (ANZALDÚA, 1999,

p. 99-101)

Por seu caráter estético, a literatura oferece à audiência a possibilidade de estabelecer um contato bastante íntimo com a alteridade do sujeito enunciador e, a partir daí, possibilita o desencadeamento de um processo de autoquestionamento e reflexão sobre a experiência pessoal de cada um, o que pode levar o receptor do enunciado a reconhecer sua própria alteridade e, em última instância, a promover ou participar em transformações sociais e políticas que impactam toda a coletividade. Assim, para usar como exemplo ainda esse livro tão fundamental na obra da autora chicana, Borderlands é não só uma afirmação da identidade pessoal da escritora e um chamado a outras mulheres de cor ou àqueles que ocupam um espaço fronteiriço na sociedade, como também é um instrumento de conscientização do público leitor sobre desigualdades e injustiças sociais.

Entretanto, sugere Anzaldúa, transformações sociais só são possíveis uma vez que haja, antes de mais nada, transformações em nível individual. Esta é uma importante proposta que a autora chicana apresenta por meio de sua obra: ao expor sua vida pessoal - percalços, desafios, obstáculos e vitórias pessoais - ela nos convida a também assumir o risco de nos expormos, a também esmiuçarmos nossa identidade e nossa relação com a realidade social. Deste modo, a obra de Anzaldúa é um exemplo contundente do caráter dialógico do objeto estético, caráter esse que a escritora performatiza em muitos dos seus textos, como, por exemplo, em "Una carta a escritoras tercermundistas," ensaiocarta em que a autora procura alcançar uma maior "intimidade" e "imediação" (ANZALDÚA, 1988, 
p. 219) com seu/sua interlocutor/a. Neste texto, Anzaldúa descreve-se a si mesma escrevendo uma carta, enquanto imagina sua destinatária, outra escritora do Terceiro Mundo, ocupada na mesma atividade da escrita: "miro de fijo mi mano morena agarrada de la pluma y pienso en ti, miles de millas de aquí agarrada de tu pluma" (ANZALDÚA, 1988, p. 223). ${ }^{1}$

Através dessa imagem especular de duas mulheres escrevendo, Anzaldúa representa uma proximidade, uma relação íntima entre toda uma comunidade de escritoras que formam, para a autora chicana, sua "família" e a quem ela chama à ação através da literatura. Esse chamado estende-se a uma rede maior de relações que inclui também o público leitor. Assim, através da palavra moldada por uma intenção estética, a escritora comparte não só sua história e suas lutas pessoais, como também convida a uma reflexão individual e à atuação social e política. A proposta de Anzaldúa é, em última instância, a literatura como forma de conscientização, como meio de atuar no mundo e promover justiça e igualdade social. A literatura coloca-se então em contrapartida ao discurso dominante, ao discurso oficial, acadêmico, regrado, graças à sua qualidade estética, permitindo a suspensão dos limites entre o pessoal e o subjetivo por um lado, e a coletividade e a realidade chamada "objetiva" por outro.

Daí que, ao exortar outras mulheres a escrever, a autora aconselha a desfazerem-se de “... lo abstracto y el aprendizaje acadêmico, las reglas, el mapa y el compás. Para tocar más gente, las realidades personales y lo social se tienen que evocar-no a través de la retórica sino a través de la sangre y la pus y el sudor" (ANZALDÚA, 1988, 227). A exortação de Anzaldúa lembra a de outra autora feminista, a francesa Hélène Cixous que, em "Le rire de la Méduse" (1975), conclama a mulher a produzir uma escrita do corpo; a mulher deve escrever-se em seu texto: "Woman must put herself into the text - as into the world and into history - by her own movement" (CIXOUS, 1976, p. 875). Ao escrever e inscrever sua identidade na sua literatura, a mulher assume a posição de agente produtor do discurso e pode então inserir-se como participante no processo social e político. Deste modo, a escrita funciona como um instrumento de transformação tanto pessoal como pública: “Writing is precisely the very possibility of change" (CIXOUS, 1976, p. 879). Observe-se que Cixous fala em terceira pessoa e dirige-se a uma "mulher," no singular, embora afirme nesse mesmo ensaio que não existe uma mulher genérica ou típica (CIXOUS, 1976, p. 876). Anzaldúa, por sua vez, fala claramente de sua própria identidade como se dirige a outras "mulheres de cor" e a outros indivíduos que, como ela, têm ocupado o entre-lugar da sociedade capitalista, eurocêntrica e heterossexista.

Em sua obra seminal, Borderlands, Anzaldúa resgata uma identidade fronteiriça, híbrida, mestiça, situada no entre-lugar, na qual duas culturas em conflito, a mexicana e a anglo-americana (des) encontram-se. Anzaldúa apropria-se da adjetivação "mestiça" e propõe-nos um novo sujeito mulher, a nova mestiça, e apropria-se também do conflito para torná-lo uma forma de diálogo. Seu texto não nos permite uma posição passiva, mas antes leva-nos, leitores, a reconhecer nossa própria posição como cidadãos de uma sociedade globalizada, na qual é necessário negociar continuamente a identidade de cada um. Assumindo o conflito como uma das tonalidades nesse livro polifônico, a escritora afirma em Borderlands a possibilidade de que "alterity is power" (SALDíVAR-HULL 5), ou seja, a própria alteridade do sujeito representa o seu poder e a sua agência frente ao discurso dominante. Cabe aqui lembrar o que Hans Robert J auss (1989) afirma sobre o caráter dialógico da comunicação literária, a qual, segundo o crítico, torna possível o reconhecimento e a aceitação da posição do Outro em sua alteridade por meio do diálogo entre quem escreve, quem lê, e o texto (JAUSS, 1989, p. 207).

Por outro lado, diz Jauss, esse diálogo torna-se problemático ou inexistente quando a alteridade (do/a autor/a, do/a leitor/a ou do texto) não é reconhecida ou aceita. Entende-se que o dialogismo nasce de uma prática hermenêutica que o objeto estético requer, e que essa prática "arises from productive and receptive interaction with art" (JAUSS, 1989, p. 208). Deste modo, a hermenêutica da obra literária é, por sua própria natureza, "most able to render communicable that which . . . the political or juridical document suppresses or passes over in silence" (JAUSS, 1989, p. 208). Assim, a obra de Anzaldúa é, como se viu anteriormente, eminentemente carnavalesca, já que nos permite uma aproximação ao Outro e, a partir da diferença deste, alcançar um entendimento mais rico de nossa própria identidade. Anzaldúa, afirma AnaLouise Keating,

By incorporating her own life into her work.... transforms herself into a bridge and creates potential identifications with readers from diverse backgrounds. She models a process of selfdisclosure which invites (and sometimes compels) us to take new risks as we reflect on our own experiences. (KEATING, 2000, p. 2). 
Lembremos que o comentário de Keating evoca o título de um dos primeiros livros de Anzaldúa, o já citado This Bridge Called My Back. A imagem do corpo da escritora como uma ponte ("bridge") constitui uma metáfora veemente para representar o caráter dialógico da literatura e da arte em geral, e o papel que cumprem em estabelecer uma "ponte," uma conexão entre o Eu criador e o Eu receptor com o objetivo não só de transmitir uma mensagem, mas também de fazer com que esse receptor torne-se, afinal, também sujeito criador de um novo discurso. A prática hermenêutica, que segundo J auss tem lugar a partir de uma interação produtiva com o objeto estético, representa uma primeira etapa do processo de formação do sujeito receptor da obra de arte; esse processo passa por uma etapa de reflexão e autorreflexão e logo conscientização social e atuação no espaço público, sempre numa dialética que envolve o âmbito pessoal e o coletivo. Deste modo, a obra de arte pode ser muito mais eficaz em comunicar realidades às quais não temos acesso imediato, já seja por causa da censura em tempos de exceção política, já seja por desinteresse da mídia, ou ainda pela própria alteridade de tais realidades em relação à nossa como consumidores da obra de arte.

Isto explica também por que a literatura de Anzaldúa, assim como a de muitas outras escritoras latino-americanas - como, por exemplo, as chilenas Isabel Allende e Marjorie Agosín, ou as brasileiras Esmeralda Ribeiro e Eliane Potiguara - , é também um intento de dar testemunho sobre a situação social e política daqueles que não têm voz: no caso de Allende, os presos políticos durante a ditadura de Pinochet; no de Ribeiro, a situação de discriminação racial que os afrodescendentes ainda sofrem no Brasil; e no de Agosín, a situação de grupos vários que têm sofrido violência, perseguição ou morte, como as mulheres que ela representa na série de poemas "Death in the Desert: The Women of Ciudad Juárez"2:

. . . las desaparecidas de Juárez son pobres

Sus vidas son oscuras como su piel Vienen de lugares extraños de la zona de Chihuahua

Algunos de Durango.

Son delgadas y jóvenes

Sin caras de porcelana.

Nadie conoce sus apellidos:

Hidalgo, Pérez, Fernández

Nadie desea conmemorar sus muertes

Las señoritas extraviadas de Juarez No tienen dinero

Mejor no hablar de ellas.

Cada noche alguna muerte

Y en el amanecer es una prisión de miedo

En las ciudades fronterizas es posible

No llegar nunca a ninguna frontera. (Agosín, 2003, p. 199-200)

Neste poema Agosín dá voz a essas mulheres repetidamente emudecidas, não só por quem as violou e assassinou, mas também por todos os que calaram frente aos seus corpos brutalizados e preferiram não investigar suas mortes. Esse silêncio, que fica bem marcado no espaço em branco entre as estrofes (essas pausas ocorrem em todos os poemas da série), deve-se ao pouco caso que a marginalização dessas mulheres - mulheres de cor, "sem caras de porcelana," pobres, hispanas - desperta nos demais.

Fica claro que essas mulheres sofrem o mesmo tipo de discriminação que Anzaldúa denuncia em sua obra. Agosín, por sua vez, vê uma profunda relação entre a violação e a morte dessas mulheres jovens e os desaparecidos na América Latina durante as ditaduras militares (2003, p. 194). As ditaduras do Chile e da Argentina, aliás, levaram Agosín a publicar várias coleções de poemas sobre a situação nesses países, dando testemunho não só pelos que foram presos, torturados e desaparecidos, mas também pelos que perderam seus entes queridos. Segundo a poetisa chilena, a poesia, com sua linguagem "íntima, pura e autêntica" (AGOSí N, 2003, p. 194), oferece possibilidades muito maiores de comunicar uma realidade urgente que é ao mesmo tempo política e privada, e de preencher a lacuna deixada por outros meios de comunicação:

The possibilities of language reside in the possibilities of faith; they are a form of redeeming and correcting world history. ... These poems [ "The Women of Ciudad J uarez"] were written by a spirit that wishes to be part of a history that does not cover but on the contrary reveals and is clear in the blinding light of every silence. (AGOSín, 2003, p. 195). 
Eliane Potiguara (n. 1950), por sua vez, é ativista política conhecida por sua luta em prol dos direitos humanos dos povos indígenas brasileiros. Seu trabalho vem sendo divulgado principalmente por meio da Internet, em blogs, e-books, seu website pessoal e outros como "You Tube," e inclui artigos sobre o movimento indígena, ensaios, entrevistas e boletins informativos, além de poesia e prosa criativa. Potiguara publicou também vários livros sobre a questão indígena, assim como um livro dirigido ao público infanto-juvenil, o coco que guardava a noite (2012), baseado numa lenda indígena. Seu livro Metade cara, metade máscara (2004), um livro polifônico de gênero híbrido, pois utiliza não só diferentes registros linguísticos, como também diversos gêneros literários, trata da questão indígena por meio de vários personagens femininos, fictícios e reais. Segundo Potiguara, a mulher indígena é instrumental na preservação das culturas e das tradições indígenas e por isso ocupa uma posição central tanto em seu ativismo político como em sua literatura. ${ }^{3}$

Para a autora, militância política e literatura representam duas facetas de uma mesma proposta e um mesmo engajamento: contar as histórias, as lutas e a memória dos povos indígenas como forma de defender seus direitos, resgatar o que lhes foi tomado pelos colonizadores e neocolonizadores e preservar suas culturas. Entretanto o caráter ficcional e poético de Metade cara abre um canal de comunicação mais amplo que envolve o receptor do enunciado no processo comunicativo e criativo. Ou seja, a dimensão que normalmente entendemos como propriamente "literária" confere ao texto níveis múltiplos de significado que favorecem a compreensão dialógica de que fala Bakhtin e que é suprimida no texto de caráter puramente político ou informativo.

Metade cara, metade máscara apresenta um discurso polifônico e multidimensional, coerente com a identidade do sujeito feminino pertencente a minorias étnicas, pois esse sujeito encontra-se em uma situação limítrofe dentro do espaço social, a qual o obriga a constantemente negociar com discursos culturais diversos. Desse modo, além da poesia e da prosa narrativa, a autora vale-se em Metade cara da tradição oral dos contadores de histórias, dos cânticos de cerimoniais indígenas, da autobiografia e do estudo sociológico; o tom que emprega é também vário - poético, lírico, épico, ensaístico e combativo. Seu objetivo, em última instância, é prestar testemunho sobre a situação de alienação, deslocamento e fragmentação que os povos indígenas vivem, por meio da situação específica da mulher. Por exemplo, no poema "Brasil," a voz poética indaga:

Que faço com a minha cara de índia?

E meus cabelos

E minhas rugas

E minha história

E meus segredos?

Que faço com a minha cara de índia?

E meus espíritos

E minha força

E meu Tupã

E meus círculos?

Que faço com a minha cara de índia?

E meu sangue

E minha consciência

E minha luta? E nossos filhos?

Brasil, que faço com a minha cara de índia? (Potiguara, 2004, p. 34)

O poema expressa a situação conflituosa em que se encontra a mulher indígena, pois se por um lado esta procura afirmar sua identidade/alteridade; por outro deve empreender um grande esforço de autoafirmação, já que sua alteridade pode também levar a sentimentos de fragmentação e alienação quando confrontada e invalidada pela cultura dominante. Entretanto a indagação que a autora coloca neste e em outros trechos de Metade cara constitui mais do que uma pergunta retórica para efeitos poéticos, sendo também uma pergunta dirigida àqueles que a leem, convidando-nos a refletir sobre a questão indígena no Brasil e a buscar uma resposta concreta, uma solução para a situação de marginalização, de "refugiados" em sua própria terra que vivem os indígenas brasileiros.

Desta forma, o processo estético, o ativismo político e a conscientização social são indissolúveis para Potiguara, que afirma: “educação e literatura passam a constituir ferramentas altamente ideológicas para nós, povos indígenas: instrumentos de conscientização" (2005, n.p.). Sua literatura vai ser 
também um chamado às mulheres indígenas para que criem, pois Potiguara reconhece no ato criativo, na linguagem estética, instrumentos de transformação social e política: “CRIEMOS, então. . . porque a criação é um ato divino que tende a mudar consciências, formar opiniões, suavizar o individualismo que ronda as mentes" (POTIGUARA, 2004, p. 58). Vemos aqui, portanto, uma exortação à criação estética como ação política, tal como se viu antes em Anzaldúa e em Cixous. Essa ação política, originada no ato criativo pelo sujeito do enunciado, complementa-se no processo hermenêutico que o receptor do enunciado realiza e que requer, antes de mais nada, uma postura de reflexão crítica.

Tal como em Anzaldúa, a obra literária de Potiguara representa também um ato de resistência novamente personificado na figura da mulher indígena, que a autora retrata como "guerreira," como o "self [sic] selvagem" (2004, p. 83), uma força espiritual capaz de catalisar mudanças sociais e políticas, num movimento de resistência contra a cultura hegemônica e masculinista como, por exemplo, no poema "Neste século de dor":

Neste século já não teremos mais bucetas Porque ser mãe neste século de morte É estar em febre pra sub-existir É ser fêmea na dor Espoliada na condição de mulher.

Não temos mais vagina, não mais procriamos Nossos maridos morreram. E pra parir crianças doentes Pra que matem nossos filhos E os joguem nas valas Nas estradas obscuras da vida Neste mundo sem gente Basta um só mandante

Neste século não teremos mais jeito Trejeitos, beleza, amor ou dinheiro. Neste século, oh Deus (?!)

Não teremos mais jeito. (POTIGUARA, 1994, p. 78).

Potiguara apresenta aqui uma visão da maternidade muito diferente daquela que costuma ser representada pela arte, tanto a literatura como as artes visuais. Em vez de uma Pietá chorando seu filho morto, a poeta retrata uma mulher revoltada recusando-se a procriar, porque não deseja ver seus filhos explorados, violentados ou mortos. O tom de revolta e raiva e o uso de palavras consideradas vulgares produzem um efeito de estranhamento que impossibilita uma posição passiva frente ao poema ou à realidade que ele apresenta. Ao contrário, a raiva que aqui se manifesta exige uma reação por parte do interlocutor poético, pondo em marcha um processo de indagação, reflexão e reposicionamento frente à realidade retratada. Assim, por meio da linguagem estética servindo ao mesmo tempo de arma política, Potiguara propõe-nos por meio da afirmação da alteridade da mulher indígena a possibilidade - e necessidade - de uma nova ordem social.

\section{CONCLUSÃO: ESTÉTICA E DIALOGISMO NA SALA DE AULA}

A obra de Eliane Potiguara, assim com a de Gloria Anzaldúa e de outras escritoras latinoamericanas, tais como as mencionadas acima, exemplificam a função que a produção estética neste caso a produção literária - desempenha no processo formador do receptor da obra de arte, inclusive na formação de uma consciência social e política e de cidadania, graças ao caráter dialógico que a linguagem estética empresta ao texto. Na obra das autoras aqui discutidas, a literatura não é um simples instrumento panfletário, mas é, sim, um instrumento catalisador de transformações sociais e políticas. Cabe esclarecer que o conceito de estética extrapola uma filosofia abstrata do "belo," sendo este, por um lado, claramente uma categoria subjetiva e, por outro, canonizada pelo discurso dominante, e como tal passível de ser questionada e subvertida, tal como se vê no poema de Potiguara "Neste século de dor."

Ao contrário, o conceito de estética aparece indissoluvelmente entrelaçado ao caráter dialógico da literatura, cumprindo assim um importante papel no desenvolvimento intelectual, emocional e 
político do ser humano. Por isso a estética e o diálogo devem necessariamente estar presentes também na sala de aula, no processo dialético de ensinar-aprender. Se a experiência estética refere-se, como quer Maxine Greene em Variation on a Blue Guitar, à experiência resultante do encontro entre sujeito e obra de arte (GREENE, 2001, p. 5-6), deve-se levar em conta também o encontro entre esse sujeito e o sujeito produtor do objeto estético, assim como a relação que se estabelece em torno do objeto estético entre os vários sujeitos que consomem a obra de arte (ou como caracterizei antes, os vários receptores do enunciado ou do objeto estético). No caso de um curso sobre literatura latino-americana de autoria feminina, em que se estudam obras de Anzaldúa, Potiguara, Agosín, Allende, ou ainda, Clarice Lispector, Alejandra Pizarnik, Conceição Evaristo, Hilda Hilst e outras, o processo formador do receptor abarca uma série de relações, ou "textos," para usar o termo empregado por Kristeva: a escritora, o texto literário, o/a docente, o/a aluno/a, e os demais membros do corpo discente.

Graças à sua linguagem estética e ao seu caráter dialógico, a literatura permite a aproximação entre esses vários sujeitos. A alteridade da obra literária, ao mesmo tempo em que preenche brechas deixadas em outros tipos de discurso, como o jornalístico, o político ou o historiográfico, oferece ao receptor novas perspectivas que provocam a reflexão e contribuem para seu bildung e para transformações individuais e coletivas. E nem só a obra de escritoras mais explicitamente engajadas em questões sociais e políticas produzem esse efeito catalisador. Mesmo a literatura de autoras mais voltadas para uma introspecção psicológica do Eu é capaz de levar o/a leitor/a a um processo de reflexão sobre sua própria identidade e sobre a realidade circundante.

No espaço da sala de aula o corpo discente pode reagir de modo conflituoso, mas crítico - e, portanto, positivamente, pois o conflito gera o questionamento - a esse encontro com a alteridade do texto literário e do sujeito do enunciado. Como afirmei anteriormente, o encontro ou o diálogo com o objeto estético e com o sujeito do enunciado (o agente produtor do objeto estético) requer também por parte do receptor um ato de produção, qual seja, o exercício hermenêutico, o qual desencadeia um processo que passa por vários estágios: um, encontro com o outro (objeto estético e sujeito do enunciado) e reconhecimento e aceitação da alteridade desse outro; dois, autorreflexão crítica e reconhecimento da própria alteridade por parte do receptor; três, diálogo com os demais receptores e reconhecimento e aceitação de suas alteridades; e, por último, reflexão crítica sobre a realidade representada pelo objeto estético. Esse processo caracteriza a educação e o aprendizado como uma experiência de empoderamento tanto do corpo discente como do docente, pois ambos aprendem juntos, tornando-se a educação uma experiência liberadora e agenciadora.

No curso a que me referi antes, disse uma aluna a respeito de Anzaldúa: "a primary objective of her works was to empower others to embrace their own differences" (S. M.). ${ }^{4} \mathrm{O}$ mesmo poderia ser dito das outras escritoras aqui examinadas, pois, segundo outro aluno, "the more perspectives you can get, the more prepared you are to make informed decisions" (C. $\mathrm{H}$.); e ainda, a literatura oferece "a more personal perspective on the struggle for finding one's self-identity" (A. W.). Assim sendo, a reflexão crítica, desenvolvida no exercício hermenêutico de análise da obra literária, pode ser levada a um passo adiante e com melhores resultados ainda quando o próprio corpo discente é convidado a tornar-se também sujeito produtor do objeto estético. A produção de poemas e cenas dramáticas foi um dos recursos pedagógicos utilizados neste curso e permitiu aos alunos uma compreensão mais profunda das estratégias de representação e autorrepresentação utilizadas pelas escritoras discutidas em aula, pois eles puderam expressar de maneira mais pessoal suas reflexões críticas e o diálogo hermenêutico antes estabelecido com os textos analisados.

Pode-se concluir, portanto, que a linguagem estética e o caráter dialógico da literatura cumprem um papel fundamental na formação do sujeito receptor do objeto estético, entendendo-se que a formação do sujeito inicia-se a partir do seu encontro com a obra de arte, mas se completa no diálogo que se estabelece com outros receptores do enunciado estético. A experiência estética e dialógica possibilita a constituição de uma comunidade baseada em interesses comuns que transcendem identificações de gênero, etnia, ou classe social, assim como contribui também para desenvolver um sentido de cidadania e prepara o indivíduo para atuar no espaço coletivo, na res pública. 
AGOSÍ N, Marjorie. Death in the Desert: The Women of Ciudad J uárez. In: HERNÁNDEZ, J ennifer Browdy de (Org.). Women Writing Resistance: Essays on Latin America and the Caribbean. Cambridge, Massachusetts: South End Press, 2003. pp. 191-209.

AGOSín, Marjorie. Secrets in the Sand: The Young Women of Ciudad Juarez. Buffalo, New York: White Pine Press, 2006.

ALLENDE, Isabel. La casa de los espíritus. Barcelona: Plaza y Janés, 1982.

ANZALDÚA, Gloria. Borderlands/La Frontera. The New Mestiza. 1987. 2. ed. San Francisco: Aunt Lute Books, 1999.

ANZALDÚA, Gloria. Hablar en lenguas. Una carta a escritoras tercermundistas. In: MORAGA, Cherríe; CASTILLO, Ana (Orgs.). CASTILLO, Ana; ALARCÓN, Norma (Trads.). Esta puente, mi espalda. Voces de mujeres tercermundistas en los Estados Unidos. San Francisco: ISM Press, 1988. pp. 219-28.

ANZALDÚA, Gloria; MORAGA, Cherríe (Orgs.). This Bridge Called my Back: Writings by Radical Women of Color (1981). 3. ed. Revisada. Berkeley, Califórnia: Third Woman, 2002.

BOSI, Alfredo. O ser e o tempo da poesia. 6. ed. São Paulo: Companhia das Letras, 2000.

CIXOUS, Hélène. The laugh of the Medusa. COHEN, Keith; COHEN, Paula (Trads.). In:

Signs vol. 1, no 4, 1976, pp. 875-93.

GREENE, Maxine. Variation on a Blue Guitar. The Lincoln Center Institute Lectures on Aesthetic Education. Nova Iorque: Teachers College Press, 2001. pp. 5-6.

JAUSS, Hans Robert. Dialogic Understanding in Literary Communication. In: HAYS, Michael (Org.). Question and Answer. Forms of Dialogic Understanding. Minneapolis: University of Minnesota Press, 1989. pp. 207-18.

KEATING, AnaLouise. Risking the Personal: An Introduction. In: ANZALDÚA, Gloria. Interviews/Entrevistas. Nova Iorque: Routledge, 2000. pp. 1-15.

KEATING, AnaLouise; GONZÁLEZ-LÓPEZ, Gloria. Building Bridges, Transforming Loss, Shaping New Dialogues: Anzaldúan Studies for the Twenty-First Century. In: KEATING, AnaLouise; GONZÁLEZ-LÓPEZ, Gloria (Orgs.). Bridging: How Gloria Anzaldúa's Life and Work Transformed Our Own. Austin, Texas: University of Texas Press, 2011. p. 1-16.

KRISTEVA, Julia. Word, Dialogue and Novel. In: MOI, Toril (Org.). The Kristeva Reader. Nova Iorque: Columbia University Press, 1986. pp. 34-61.

MAYOBRE, Esperanza. La amable Candelaria vive su peor momento. 2009. Instalação. Exposição Ñew York. Museu de Arte das Américas, Organização dos Estados Americanos, Washington, DC, fevereiro-maio 2012.

POTIGUARA, Eliane. O coco que guardava a noite. Rio de Janeiro: Editora Mundo Mirim, 2012.

POTIGUARA, Eliane. Entrevista a Sandra Regina S. Baldessin. In: Entreletras. Entrevistas com Escritores. Disponível em: www.abrali.com/015coluna/sandra_baldessin/eliane_potiguara. Acesso out. 2005.

POTIGUARA, Eliane. Metade cada, metade máscara. São Paulo: Global, 2004.

POTIGUARA, Eliane. Neste século de dor. In: ALVES, Miriam; DURHAM, Carolyn Richardson (Orgs.). Enfim. . . Nós / Finally Us: escritoras negras brasileiras contemporâneas. Boulder, Colorado: Three Continent Press, 1994. p. 78.

RAMA, Ángel. La ciudad letrada. Hanover, New Hampshire: Ediciones del Norte, 1984.

RIBEIRO, Esmeralda. Fato. In: ALVES, Miriam; DURHAM, Carolyn Richardson (Orgs.). Enfim. . . Nós / Finally Us: escritoras negras brasileiras contemporâneas. Boulder, Colorado: Three Continent Press, 1994. pp. 86. 
SALDí VAR-HULL, Sonia. Introdução à segunda edição. In: ANZALDÚA, Gloria. Borderlands/La Frontera. The New Mestiza. 2. ed. San Francisco: Aunt Lute Books, 1999. pp. 1-15.

SANTIAGO, Silviano. A democratização no Brasil. Cultura versus arte. In: O cosmopolitismo do pobre: crítica literária e crítica cultural. Belo Horizonte: Editora da UFMG, 2004. pp. 134-56.

SANTIAGO, Silviano. Leitor e cidadania. O cosmopolitismo do pobre: crítica literária e crítica cultural. Belo Horizonte: Editora da UFMG, 2004. pp. 168-93.

NOTAS

${ }^{1}$ Note-se que, para Anzaldúa, a escritora "tercermundista" não se encontra somente em países considerados parte do chamado Terceiro Mundo, como os países latino-americanos ou africanos. Anzaldúa reconhece a existência de um "Terceiro Mundo" inserido-e marginalizado-dentro do próprio Estados Unidos. Mulheres de cor, homossexuais e outras minorias constituem esse outro "Terceiro Mundo" e habitam assim um espaço fronteiriço, as "borderlands" que Anzaldúa descreve como "physically present wherever two or more cultures edge each other, where people of different races occupy the same territory, where under, lower, middle and upper classes touch, where the space between individuals has been shrinking with intimacy" (ANZALDÚA, 1999, p. 19).

${ }^{2}$ I sabel Allende (n. 1942), no seu romance histórico La casa de los espíritus (1982), dá testemunho sobre a condição dos presos políticos chilenos através da situação da personagem Alba Trueba, que é presa e torturada. Marjorie Agosín (n. 1955), de origem judia e residente nos Estados Unidos, é poeta premiada, crítica literária e ativista. Sua obra enfoca situações de violação dos direitos humanos, principalmente de mulheres. Nos poemas da série "The Women of Ciudad Juárez" ela dá voz às centenas de mulheres anônimas assassinadas e esquecidas nessa cidadezinha mexicana perto da fronteira com os Estados Unidos. Esses assassinatos, somando muito mais de 350 casos, foram de modo geral ignorados pelas autoridades mexicanas e pela mídia dos dois países. Os poemas de Agosín foram publicados pela primeira vez em 2003 e mais tarde no seu livro Secrets in the Sand (2006).

${ }^{3}$ Para um estudo mais amplo de Metade cara, metade máscara, ver meu ensaio "Uma nova Iracema: a voz da mulher indígena na obra de Eliane Potiguara" (Brasil, Brasis, ou: A hora e a vez das minorias étnicas. Org. Cristina Ferreira-Pinto Bailey e Regina Zilberman. Revista I beroamericana 76.230 (2010): 201-15).

${ }^{4}$ Este curso foi ensinado na primavera de 2012 (abril-maio). Para preservar a privacidade dos alunos incluo aqui somente as iniciais de seus nomes.

Artigo recebido em 02/08/2012

Aprovado em 27/08/2012 
CONTRAPONTOS

290 Ana Cristina Ferreira-Pinto Bailey - Estética e dialogismo: o papel da literatura na ... 
CONTRAPONTOS 